THE PLEASURES OF MEMORY 
This page intentionally left blank 


\section{THE PLEASURES OF MEMORY}

Learning to Read with Charles Dickens

Sarah Winter

Fordham University Press

New York 20I I 


\section{Copyright (C) 20I I Fordham University Press}

All rights reserved. No part of this publication may be reproduced, stored in a retrieval system, or transmitted in any form or by any means-electronic, mechanical, photocopy, recording, or any other-except for brief quotations in printed reviews, without the prior permission of the publisher.

Fordham University Press has no responsibility for the persistence or accuracy of URLs for external or third-party Internet websites referred to in this publication and does not guarantee that any content on such websites is, or will remain, accurate or appropriate.

Fordham University Press also publishes its books in a variety of electronic formats. Some content that appears in print may not be available in electronic books.

Library of Congress Cataloging-in-Publication Data

Winter, Sarah.

The pleasures of memory : learning to read with Charles Dickens / Sarah Winter--Ist ed.

p. $\mathrm{cm}$.

Includes bibliographical references and index.

ISBN 978-0-8232-3352-6 (cloth : alk. paper)

ISBN 978-0-8232-3354-0 (ebook)

I. Dickens, Charles, I8I2-I870-Influence. 2. Collective memory and literature. 3. Books and reading-Psychological aspects. 4. Books and reading-History — I 9 th century. I. Title.

$\mathrm{PR}_{4588 .}$. W6 20I I

$823^{\prime} .8-\mathrm{dc} 22$

2010050791

Printed in the United States of America

$\begin{array}{llllllll}\text { I } 3 & \text { I } 2 & \text { II } & 5 & 4 & 3 & 2 & \text { I }\end{array}$

First edition 
For Panos and Alexia 
This page intentionally left blank 